\title{
Forecasting the Contribution of Universities to Urban Development
}

\author{
Daneykin Yu.V. \\ Yaroslav-the-Wise Novgorod State University, \\ Veliky Novgorod, Russia, \\ yury.daneykin@novsu.ru
}

Erznkyan B.A.

Central Economics and Mathematics Institute RAS,

Moscow, Russia,

lvova1955@mail.ru

\author{
Ivanova O.P. \\ Yaroslav-the-Wise Novgorod State University, \\ Veliky Novgorod, Russia, \\ prof-ivanova@mail.ru
}

Trifonov V.A.

Yaroslav-the-Wise Novgorod State University, Veliky Novgorod, Russia, tva@novsu.ru

\author{
Belchik T.A. \\ Kemerovo State University, \\ Kemerovo, Russia, \\ t.a.belchik@mail.ru
}

\begin{abstract}
The article presents the results of the authors' development of an approach to forecasting the effects of the development of the "City-University" ecosystem. The directions of modernization of university campuses, domestic and foreign examples of the development of university cities are considered. The importance of strengthening the role of universities in the progress of the urban environment is considered. Recommendations were formed on planning the effects from the implementation of the third mission of the university based on the analysis of the approaches used in practice to assess the contribution of universities to regional and urban development, considering the directions of the City-University strategy implemented in the Novgorod region. The forecast estimates of the contribution of the Yaroslav-the-Wise Novgorod State University to the economic growth of the city of Veliky Novgorod are presented. Prospective points of development of the "CityUniversity" ecosystem, aimed at improving the image and increasing the attractiveness of the city are proposed.
\end{abstract}

Keywords-ecosystem "City-University",

university contribution, university campus, development

\section{INTRODUCTION}

Universities become catalysts for the economic development of countries and regions, centers of social, scientific, and cultural life of cities. They contribute to the creation of public spaces and implement technologies for sustainable development of territories. The importance of universities in the innovative development of regions and cities, the country, is increasing. Transformations of the education system have taken place and will continue to grow. The processes of interaction between scientific, educational organizations and organizations of the real sector of the economy are changing. The crisis, the pandemic revealed the personal involvement of universities to the challenges that arise before society, the economies of countries and regions. The desire of universities to have a beneficial effect on the development of regions and cities (the "third" mission) has been studied for a long time and on a large scale. Responsible behavior of the university in relation to the city and region of its residence is in demand.

Universities are significant actors in the regional and urban economies; they should be full-fledged participants in regional economic planning. This is necessary because universities have unique distinctive features: unlike most enterprises, they are historically one of the most durable institutions [1]. Universities can demonstrate leadership, promote integration in planning and promote the economic development of a country, region, and city [2]. In the context of the integration of universities into the agenda of the spatial and scientific and technological development of the country, strengthening the work on the interaction of universities, scientific organizations, and industrial enterprises, it is necessary to plan the contribution of universities to the development of cities and regions. And here, determining the effects of the activities of universities on the development of the urban environment, the economic growth of cities, improving the social well-being of residents is of great importance.

Many countries pay attention to the development of university campuses and the influence of universities on the successful development of cities: China [3, 4], Great Britain, Austria, the Netherlands, France, and others [5-12]. For 
example, Guangzhou has 10 universities connected by a common socio-cultural infrastructure, transport, and engineering systems, and is part of a regional cluster [6-8]. The creation of the new campus of the Vienna University of Economics in Austria in 2013 was a catalyst for the development of the urban environment [12].

Among the activities for the development of cityuniversity campuses, one can distinguish not only an increase in the quality of the urban environment, filling the urbanized territory with system-forming functions - education, culture, public lectures, recreation, libraries, cafes, but also the use of unique landscape features. One of the striking examples of a university city is Tomsk, the cultural and educational center of Siberia [13]. This city is a conglomerate of academic, technological, cultural, scientific, and innovative features, characterized by a high level of innovative entrepreneurship of teachers, researchers, students.

In addition, universities are becoming well-equipped sites for the birth and development of enterprises, including hightech ones. Business incubators, technology valleys, technical schools created by universities allow the production of technologies of the future, and large industrial companies implement scientific and technical developments, and industrialize them.

When predicting the contribution of the university to the development of the city, it makes sense to use the provisions of the concept of "multiversity" [14] - a set of students, graduate students, teachers, scientists, humanities, and naturalists, "keeping eternal truths and creating new truths".

When predicting the contribution of universities to urban development, it is important to use both economic assessments and other indicators that are important for different areas of the urban environment. So, when using the economic approach [15], one can get an answer to the questions: "What would happen if there was no university in the region?", "How much would the income of the population and the number of jobs decrease in this case?". The use of a skill-based approach that expands the set of criteria for assessing the impact of higher education on the regional economy by adding elements of assessing the level of qualifications of workers ("skillbased" approach) [16] to the traditional approach, it is possible to determine the impact of higher qualifications on the growth of significant regional indicators of socio-economic development.

Short-term and long-term effects should also be distinguished [17]. In the short term, it is possible, for example, to estimate the amount of funds attracted to a region or city from the expenses of students and teachers, the expenses of the university. In the long term, new sectors of the economy, companies, and enterprises (created by graduates and teachers at the university), a new class of highly qualified personnel are being formed. Thus, it is possible to evaluate the effects of the formation of new industries, technological developments, etc. Scientists, including R. Huggins, P. Cook, D. Charles, P. Benneworth, G. Itskowitz, D. Bock, etc. [18] analyze how universities produce new knowledge and technologies, introduce them into regional socio-economic and production systems [19].

The authors are developing a methodology for predicting the contribution of the university to the development of the
"City-University" ecosystem. In this article, we will present the main components of the city development strategy in integration with the university, key areas of long-term progress and methods of planning the effects from the implementation of the tasks.

\section{RESULTS}

Implementation of the "City-University" strategy requires not only the identification of key mechanisms for achieving strategic goals, but also forecasting the contribution from the functioning and progress of the university to the development of the city.

The goal of the "City-University" strategy being implemented in Veliky Novgorod is to create a comfortable urban environment and the combined development of the city and the university. Among the tasks, the development of the campus as one of the two key city-forming segments (along with the museum and historical one), the examination and design of urban public spaces, the formation of a positive image of the city, an increase in the number of students at Yaroslav-the-Wise Novgorod State University to 30.000 by 2030, an increase in the share of foreign students up to $15 \%$.

Among the predicted results, the following effects for the urban environment and society are highlighted.

First, the development of internal and external collaboration, namely the attraction of leading specialists in the field of urban studies to the university and the city, which will allow the formation of interdisciplinary scientific, educational and project clusters within the university, establish working relations with domestic and foreign scientific, design, expert, educational, and media institutions.

Secondly, an important effect of the "Visual Ecology" direction will reduce the negative load on the psyche of students and teachers, the formation of positive emotions, an increase in creative mood, the creation of an attitude to participate in common activities, strengthening the desire to belong to a corporation.

Thirdly, the effect of the creation and development of sites for university and city events, the integration of the university into the urban cultural space, the formation of visual markers of the city-university and the promotion of Novgorod identity in the city and the region.

Fourth, the creation and strengthening of an attractive image of synergy between the city and the university will allow achieving not only strengthening of competitive advantages in the market of educational services, but ensuring an increase in the number of students, including talented ones, ensuring the growth of investments in the future of the region.

Fifth, the effect of attracting and developing small businesses on the campus (cafes, shops, service, etc.) will increase the contribution to the economy of the city and the region.

Sixth, the effect of the development of the urban growth point is the development of the campus as a leading segment of the urban environment in general, the introduction of advanced achievements in the field of communication technologies and design, the spatial implementation of the "City-University" concept. 
Seventh, the economic effect of the growth in the number of students. It is also due to the growth in the number of faculty members (FM) of the university.

Let us present some formulas for calculating the long-term economic effect from an increase in the number of students at the university and the obtained forecast estimates (Table I).

So, the growth in the number of students, teaching staff, the arrival of new teaching staff with families and children determine the growth of consumption, an increase in the number of organizations and enterprises in the region that satisfy the growing consumption, the need for the construction of new housing for teaching staff, apartment buildings rented housing for foreign students, hostels, etc.

The increase in the volume of shipped goods (IVSG) of own production of manufacturing industries in the region due to the increase in students, faculty members (FM) and members of their families can be determined by the (1):

$$
I V S G=S G * I S * 0.70+S G * I F M
$$

SG - shipment of goods per inhabitant, rubles; IS - increase in students (people); 0.70 - conditional coefficient of student consumption from the average value per inhabitant in the region $(70 \%)$; IFM - increase in faculty members with family members (people).

An increase in the number of enterprises and organizations for the production of goods of their own production can be planned using the (2):

$$
N N E=I V S G / A S G_{\text {org }}
$$

NNE - the number of new enterprises for the production of goods of own production, performance of work, services using own resources (excluding small businesses) in the city, units; IVSG - increase in the volume of shipped goods of own production of manufacturing industries in the city, million rubles; $\mathrm{ASG}_{\text {org }}$ - average shipment of goods and services per organization in the city, million rubles.

The average shipment of goods and services per enterprise in the city ( $\left.\mathrm{ASG}_{\mathrm{org}}\right)$ is defined as (3):

$$
A S G_{\text {org }}=S P O P / N E O P
$$

SPOP - goods of own production were shipped, works and services performed on their own resources (excluding small businesses), million rubles; NEOP - the number of enterprises for the production of goods of their own production, performance of work, services on their own resources (excluding small businesses) in the city, units.

The increase in the volume of work performed for the type of economic activity "construction" in the region is due to the growing demand for housing.

In this case, we can plan in the long term the number of required new houses $(\mathrm{NNH})$ for the faculty members $(\mathrm{FM})$ and their family members (4):

$$
N N H=T A R P * I F M / A A R P
$$

TARP - the total area of residential premises per one resident of Veliky Novgorod, sq. m.; IFM - increase in faculty members with family members (people); AARP - the average area of residential premises of new residential buildings commissioned in the region, sq. $\mathrm{m}$.

TABLE I. PLANNED ECONOMIC EFFECTS FROM AN INCREASE IN THE NUMBER OF STUDENTS AT THE UNIVERSITY BY 2030 UP TO 30.000 PEOPLE

\begin{tabular}{|c|l|l|}
\hline & \multicolumn{3}{|c|}{ Planned economic effects } \\
\hline 1 & $\begin{array}{l}\text { Construction of new } \\
\text { housing for FM (90\%- } \\
\text { apartments, 10\% } \\
\text { cottages) }\end{array}$ & $\begin{array}{l}\text { The growth of the teaching staff and their } \\
\text { family members is 2000 people. } \\
\text { The number of 40 apartment (60 sq. m.). } \\
\text { Residential buildings - 20 houses. } \\
\text { Number of cottages (75 sq. m.) }-88 \\
\text { cottages. }\end{array}$ \\
\hline 2 & $\begin{array}{l}\text { Construction of } \\
\text { apartment buildings }- \\
\text { rental housing for } \\
\text { international students } \\
\text { (60\% of foreigners are } \\
\text { from far abroad) }\end{array}$ & $\begin{array}{l}\text { The contingent of foreign students (from } \\
\text { far abroad) } 2700 \text { people. } \\
\text { The number of apartments (2 room } \\
\text {-675 units: 1 or 2 superior dormitories. }\end{array}$ \\
\hline 3 & $\begin{array}{l}\text { Dormitory construction } \\
\text { The number of visiting students in need of } \\
\text { a hostel is 6100 people. } \\
8 \text { hostels with 750 beds. }\end{array}$ \\
\hline
\end{tabular}

In addition, the implementation of the "City-University" strategy involves the development of a university campus, the formation of a barrier-free environment at all levels, the use of car sharing at points of entry into the general urban environment, the launch of a branded campus route (electric bus with Wi-Fi, smart stops). This will provide communication between individual locations within the campus, as well as with key urban infrastructure facilities (railway station and bus station, the Kremlin, theaters, shopping centers). This development direction is aimed at turning the campus into a technology-innovation zone for advanced humanitarian and technological innovations.

The strategic vision of the city is considered as the formation of the "City-University" ecosystem. In this case, the key points of growth are planned: the creation of a human capital development fund, the creation of a venture fund, the introduction of digital solutions for monitoring the state of the urban environment by the "Smart City" Competence Center, the inclusion of experts from Yaroslav-the-Wise Novgorod State University in the system of expertise and city management, collection and analysis of proposals to improve and correct the urban environment, taking into account new urban trends, holding an annual urban forum of small towns, integrating educational institutions of the city, ensuring the continuity of training "School - Secondary specialized education - Higher education", the creation of the Higher School of Local Government. The last element is aimed at training a highly professional local government specialist and further developing his competencies. The fundamental tasks of the Higher School of Local Self-Government will be the following: training students in the "Local Self-Government" profile, retraining of employees of local government bodies throughout Russia, retraining of employees of budgetary organizations.

\section{CONCLUSION}

Analysis of the practice of including universities in the economic development of countries, regions, cities, the study of the role of universities in the development of the territories of their residence, activities for the development of citiesuniversity campuses, methodological approaches to assessing 
and planning the contribution of universities to the development of cities allowed the authors to offer an original view of long-term planning of contribution University in the development of the ecosystem "City-University". The main components of the city development strategy in integration with the university are presented. The authors attach key importance to the choice of growth points for a comfortable urban environment, synergetic interaction between the city and the university. The forecast estimates in the increase in the number of students at the Yaroslav-the-Wise Novgorod State University to 30.000 people by 2030 are presented. The authors identified several effects (not only economic) from a significant increase in the number of students: the development of internal and external collaboration, visual ecology, the development of sites for university and city events, the integration of the university into the urban cultural space, the development of the campus as a leading segment of the urban environment, the creation of a development fund human capital, integration of educational institutions of the city.

\section{Acknowledgment}

The article was prepared with the support of the RFBR grant No. 18-010-00244 "Development of methodological tools for managing monotowns of the Kemerovo region using predictive analytics to ensure countering the sources of danger to society and the state economy".

\section{References}

[1] P.S. Avetisyan, and N.M. Gevorkyan, "Free educational environment as the basis of human capital and the relationship between social sectors", Economy of the region, 2020, vol. 16(2), pp. 494-506. (In Russ.). DOI: 10.17059/2020-2-12

[2] G. Boulton, D. Breimer, J. Carlstedt-Duke, I. Leslie, M. Makarow, K. Raivio, D. Livesey, and K. Maes, Universities and Innovation: The Challenge for Europe, League of European Research Universities, 2006. Retrieved from https://www.leru.org/publications/universitiesandinnovation-the-challenge-for-europe\#

[3] V.D. Shishov, "Development of green finance as a modern trend in the world economy (on the example of China)" ["Razvitiye zelenogo finansirovaniya kak sovremennaya tendentsiya mirovoy ekonomiki (na primere Kitaya)"], Bulletin of modern research [Vestnik sovremennykh issledovaniy], 2019, vol. 3.20(30), pp. 107-110. (In Russ.).

[4] L.S. Khudyakova, G20 Summit: Green Light for "Green Finance" [Sammit Bol'shoy dvadtsatki: zelenyy svet "zelenomu finansirovaniyu"], IMEMO, $2016 . \quad$ Retrieved https://www.imemo.ru/publications/relevant-comments/text/sammitbolyshoy-dvadtsatki-zeleniy-svet-zelenomu-finansirovaniyu

[5] O.V. Davydova, E.A. Lylina, and O.V. Chistyakova, "Formation of university campuses in the strategy of sustainable development" ["Formirovaniye universitetskikh kampusov v strategii ustoychivogo razvitiya"], Trends in the development of science and education [Tendentsii razvitiya nauki i obrazovaniya], 2018, vol. 45(5), pp. 57-60. (In Russ.). DOI: 10.18411/lj-12-2018-116

[6] M.V. Artamonova, Transformation of higher education in the context of the formation of a digital economy in Russia [Transformatsiya vysshey shkoly v usloviyakh formirovaniya tsifrovoy ekonomiki v Rossii], In book: Digital transformation: education, science, society [Tsifrovaya transformatsiya: obrazovanie, nauka, obshchestvo], M.: Moscow Polytech, 2019, pp. 160-168. (In Russ.).

[7] M.G. Zobova, "Modern principles of architectural and urban designing of university campuses", Vestnik of the Orenburg State University, 2015, vol. 3(178), pp. 243-248. (In Russ.).

[8] G.V. Fayzieva, and E.A. Shevelev, "University campus - the base of modern educational landscape foundation", Humanities and education [Gumanitarnye nauki i obrazovanie], 2017, vol. 2(30), pp. 70-74. (In Russ.).

[9] N.A. Ovchinnikova, and A.M. Krygina, "Ecological reconstruction of university campuses" ["Ekologicheskaya rekonstruktsiya universitetskikh kampusov"], In Proceedings of IV ISPC on Energy Efficiency, Resource Conservation and Environmental Management in Urban and Construction: Economics and Management [Energoeffektivnost', resursosberezheniye i prirodopol'zovaniye v gorodskom khozyaystve i stroitel'stve: ekonomika i upravlenie], 2017, vol. 2, pp. 87-94. (In Russ.)

[10] E.S. Paley, "Green public space in composition of modern European university campuses", Academia. Architecture and Construction, 2017, vol. 4, pp. 55-61. (In Russ.).

[11] E.S. Paley, "Square in modern European university campus", Regional architectural art schools [Regional'nye arkhitekturno-khudozhestvennye shkoly], 2018, vol. 1, pp. 48-51. (In Russ.)

[12] T.V. Gagnidze, and N.V. Gudz, "Development of the city of Perm by way of interaction between the city and the campuses", PNRPU Bulletin. Applied ecology. Urban development, 2017, vol. 1(25), pp. 19-32. (In Russ.).

[13] Yu.V. Podoprigora, T.V. Zakharova, E.V. Ufimceva, and A.M. Eliseev, "Sociocultural environment of the university city: administrative aspect", Municipality: economics and management, 2019, vol.1(26), pp. 50-57. (In Russ.)

[14] I.V. Brylina, and A.A. Kornienko, "The process of formation of enterprise university. Apology of cultural mission of the university", Tomsk State University Journal of Cultural Studies and Art History, 2016, vol. 2(22), pp. 28-36. (In Russ.).

[15] D.S. Elliott, S.L. Levin, and J.B. Meisel, "Measuring the economic impact of institutions of higher education", Research in Higher Education, 1988, vol. 28(1), pp. 17-33.

[16] B. Bluestone, UMass/Boston: an economic impact analysis, Boston: John W. McCormack Institute of Public Affairs, University of Massachusetts, 1993.

[17] H. Battu, and J. Finch, "Integrating knowledge effects into university impact studies. A case study of Aberdeen University", Working papers from Department of Economics, University of Aberdeen, 1998, vol. 5.

[18] R. Huggins, and A. Johnston, "The Economic and Innovation Contribution of Universities: A Regional Perspective", Environment and Planning C: Government and Policy, 2009, vol. 27(6), pp. 1088-1106.

[19] P. Benneworth, and D. Charles, "University spin-off policies and economic development in less successful regions: Learning from two decades of policy practice", European Planning Studies, 2005 , vol. 13(4), pp. 537-557. DOI: 10.1080/0965431050010717 